S.N. Sen

The Asiatic Society, 1 Park Street, Calcutta India.

The origin and development of planetary theories in India are still imperfectly understood. It is generally believed that fullfledged planetary theories capable of predicting the true positions of the Sun, Moon and Star-planets appeared in India along with the emergence of the siddhäntic astronomical literature. Before this siddhāntic astronomy there had existed the Vedánga Jyotișa of Lagadha, prepared around circa 400 B.C. in the sutra period more or less on the basis of astronomical elements developed in the time of the Samhitās and the Brähmanas. This Jyotișa propounded a luni-solar calendar based on a five-year period or yuga in which the Sun made 5 complete revolutions. Moreover, this quinquennial cycle contained 67 sidereal and 62 synodic revolutions of the Moon, 1830 sāvana or civil days, 1835 sidereal days, 1800 solar days and 1860 lunar days. An important feature of the Jyotișa is its concept of the lunar day or $t$ ithi which is a thirtieth part of the synodic month. The tithi concept was also used in Babylonian astronomy of the Seleucid period. To trace the motion of the Sun and the Moon and to locate the positions of fullmoons and newmoons in the sky a stellar zodiac or a nakșatra system coming down from the times of the Samhitās and the Brāhmañas was used. The Jyotiṣa was acquainted with the solstices and equinoxes, the variation in day-length of which a correct ratio was given. It is, however, silent about the inclination of the ecliptic, the non-uniform and irregular motion of the Sun and the Moon and various other important elements.

of pre-siddhāntic astronomy mention should also be made of the Jaina Upangas, the Suryaprajnapti and the Candraprajnapti. These texts were written in ardhamägadhì prākrt possibly later than the Vedánga Jyotișa and taught a system of calendrical astronomy more or less identical with that of the Jyotisa. Then we have the Gargasamhita (1st century A.D.) and Paitamaha-siddhänta belonging to the same class and containing nothing new.

Āryabhața's Äryabhatīya, compiled in A.D.499 and Varāhamihira's Pañcasiddhantika dated A.D. 505 were marked by a refreshing change in the treatment of the entire subject. The former is a succinct and highly condensed mathematical astronomical text developed around a unified sun-rise system, while the latter is a summary of five astronomical siddhäntas developed at different intervals of time and therefore of considerable historical significance. We know from varāha 
that several astronomical siddhāntas other than the five he summarized in his book had been composed before his time, but these did not survive except in a very fragmentary manner in quotations and other references. It is quite clear that some time before his time Indian astronomy underwent a fundamental change and assumed a truly scientific, that is, mathematical, character. This change involved the following among others:-

(1) The archaic stellar zodiac was replaced by the twelve signs of zodiac;

(2) Besides the study of the Sun and the Moon, the study of five other star-planets and their motions was incorporated in an enlarged Yuga system;

(3) Sophisticated mathematics like continued fractions, rule of three, trigonometry-plane as well as spherical, indeterminate equations, and geometrical models were pressed into service to develop astronomical rules, formulas, and tables with the result that planetary motions could henceforward be explained mathematically and occcurence of eclipses be correctly computed before hand.

These features characterized the compilation of astronomical siddhāntas during the next twelve hundred years until modern times, of which typical examples are Brahmagupta's Brăhmasphuta-siddhānta and Khandakhädyaka, modern Sürya-siddhänta, Bhāskara II's Siddhāntasiromani, to mention a few, and several commentaries and Karana works.

The planetary theories developed in these Sanskrit astronomical texts rest on three important concepts:-

(a) the Yuga, (b) the ahargana, and (c) the geometrical models of eccentric circles and epicycles.

\section{THE YUGA}

The Yuga is a sufficiently long period of time in which the planets execute integral numbers of revolutions. Another property of this period is that the planets should find themselves at the fixed point of the Hindu sphere at the beginning of this period (and consequently also at the end of the same period). The Vedanga Jyotișa, as already mentioned, used a 5 year luni-solar period to accommodate the periodic motions of the Sun and the Moon. The Romaka-siddhanta as summarized by Varăha, used a luni-solar period of 2850 years. This period contained 1050 intercalary months and 16547 omitted lunar days. These elements reduce to the well-known Metonic Cycle of 19 years containing 7 intercalary months. The old Suryasiddhanta summarized by Varaha had to use a still larger period, namely, 180,000 years in order to accommodate all the star-planets. Towards the end of the 5 th and the beginning of the 6 th century A.D. Äryabhata adopted the Mahāyuga containing 4,320,000_years, which is exactiy 24 times the period given in the old Suryasiddhäta. Āryabhața also adopted another smaller Yuga as one-tenth of his Mahäyuga, that is, a period containing 432,000 years which started on the midnight between February 17 and 18,3102 B.C. He called it the Kaliyuga. Other Indian astronomers, Brahmagupta, 
Bhāskara II and others, used a still larger period of time, the Kalpa which is 1000 times the Mahāyuga.

The origin of the concept of Mahāyuga for astronomical purposes is still an unsolved problem. In India, the Yuga system is met with in the laws of Manu and the Mahäbhärata. The epic discusses the division of time and defines larger units of time like the 'Year of the Gods' $\quad(=360$ ordinary year) and introduces the four mundane ages, e.g. Krta, Tretā, Dväpara and Kali with the following lengths of time:

$\begin{array}{lll}\text { Krta Yuga } & -4800 \text { years of Gods } \\ \text { Tretā Yuga } & -3600 & - \text { do- } \\ \text { Dvāpara Yuga } & -2400 & - \text { do- } \\ \text { Kali Yuga } & -1200 & - \text { do- } \\ & ---0- & \\ & 12,000 & \end{array}$

$$
\begin{aligned}
= & 1,728,000 \text { years } . \\
= & 1,296,000 " ~ \\
= & 864,000 " ~ \\
= & 432,000 " \\
& 4,320,000 \text { years }
\end{aligned}
$$

Similar ideas of great years are also met with among the Greeks, the Babylonians and the Persians. Early Greek philosophers like the Pythagoreans believed in the 'eternal return of all things' at the end of a long enough period of time. Furthermore, such cycles were marked by conflagration of great natural calamities. Van der Waerden (1980) who investigated the question of the origin of great years showed that the Greeks had a great year of Orpheus comprising 120,000 years and a great year of Cassandrus comprising 3,600,000. All these years are built out of factors 120 and 3600 . The concept of a great year associated with flood and planetary conjunctions is often ascribed to the Babylonian priest Berossus who foretold that there would be a conflagration when all planets had a conjunction in Cancer and a deluge when such a conjunction took place in Capricorn. Berossus further estimated that the sum of regnal years of mythical kings before the Flood totalled 120 saroi or 432,000 years, 1 saros being 3600 years.

Did Āryabhata adopt the period of 120 saroi or 432,000 years as his Kali Yuga period? It should be mentioned in passing that the number 432,000 can also be derived from more ancient Indian tradition such as 27 nakșatras and the number of bricks 10,800 usegd in the construction of sacrificial fire-altars as mentioned in the Satapatha Brahmana, for $4 \times 27=108 ; 27 \times 16=432 ;$ and $10,800 \times 40=432,000$. Whatever the source of Arryabhata in adopting the span of the period he did not in all probability determine the starting point of the Kali Yuga at mid-night between February 17 and 18, 3102 B.C. by backward extrapolation of planetary positions from a certain date for the obvious reason that planets were not in conjunction on the mid-night of February 17 and 18, 3102 B.C. Van der Waerden (1980) has made an ingenious suggestion that Áryabhața possibly got his clue from Persian tradition of observing and recording planetary conjunctions, particularly of the two slowest planets Saturn and Jupiter, and arrived at the date by a happy guess-work. 
In this great cycle, the Mahāyuga or Kalpa, the revolution numbers executed by each planet as also by the apsides and nodes of the Moon are given leading to a fundamental table needed for all manner of planetary computations. Table I gives such revolution numbers for the Sun, Moon and five star-planets in accordance with the Surya-siddhanta as summarized by Varāha, Āryabhata's ärdharätrika system as also reproduced in the Khandakhädyáka and Bhäskara I's Mahābhāskarīya and the modern Surya-siddhanta. The figures for inferior planets Mercury and Venus represent the revolution numbers of their conjunctions in respect of Sun, the sighra, their sidereal revolutions being the same as that of the Sun. The table gives the number of civil days, or savana days reckoned from sun-rise to sun-rise in the Mahäyuga.

Table I - Planetary Revolutions in Mahäyuga

\begin{tabular}{|c|c|c|c|}
\hline Planet & $\begin{array}{l}\text { sürya-siddhānta } \\
\text { summarised } \\
\text { oy Varähamihira }\end{array}$ & $\begin{array}{l}\text { Āryabhața I } \\
\text { (ärdharätrika system) } \\
\text { reproduced in } \\
\text { Khandakhādyaka } \\
\text { and Mahābhāskarìya }\end{array}$ & $\begin{array}{l}\text { Modern } \\
\text { Sūrya- } \\
\text { siddhānta }\end{array}$ \\
\hline$\overline{\text { Sun }}$ & 4320000 & 4320000 & 4320000 \\
\hline Moon & 57753336 & 57753336 & 57753336 \\
\hline Mars & 2296824 & 2296824 & 2296832 \\
\hline Jupiter & 364220 & 364220 & 364220 \\
\hline Saturn & 146564 & 146564 & 146568 \\
\hline Mercury & 17937000 & 17937000 & 17937060 \\
\hline Venus & 7022388 & 7022388 & 7022376 \\
\hline Moon's apogee & 488219 & 488219 & 488203 \\
\hline $\begin{array}{l}\text { Moon's node } \\
\text { Number of }\end{array}$ & 232226 & 232226 & 232238 \\
\hline a Mahāyuga & 1577917800 & 1577917800 & 1577917828 \\
\hline
\end{tabular}

It is to be noted that the starting point of these revolutions is the fixed point of the ecliptic, the first point of Ariesand that planetary motions are uniform. From this table it is easy to determine the period of each planet in days and mean daily motion in hours, minutes, seconds etc (sexagesimal units). The mean position of each planet can also be readily computed if one knows the number of civil days elapsed from the beginning of the Mahāyuga up to the date in question. With certain modifications it can also be done from the beginning of any epoch such as the Saka era.

The system has great simplicity and obviates the necessity of continuous observation. It is however necessary to observe each planet at intervals of time, note the deviations of observed positions from calculated ones and suitably amend the table of planetary revolution numbers to ensure perfect fit between observations and computations. These are 
called bijja corrections. Āryabhața revised his own ärdharātrika tables in his own life time to produce his more accurate audayika system, and later astronomers did the same to keep astronomical tables in step with the reality of planetary motions.

\section{AHARG AN A}

The number of civil or sävana days elapsed from the beginning of a Mahāyuga or epoch necessary for computing the mean position of a planet on a given date is called the ahargana. If the calendar were maintained in savana days according to the epoch, the ahargana could be immediately found from such a calendar. Not so in a luni-solar calendar where dates are kept according to a saura year equal to the time taken by the Sun to travel through 12 signs of the zodiac, a lunar month equals the time interval between two newmoons, and a lunar day or tithi is equal to $1 / 30$ th of the lunar month. The computation of civil days involves the reckoning of intercalary months and omitted lunar days ( $k s a y a \bar{a} a)$. Most astronomical siddhāntas and Karanas give rules and procedures for ahargana computations. The basic steps are as follows:-

$$
t=y \text { years }+m \text { months }+d \text { days. }
$$

Let us suppose that, in this time period, the number of saura, lunar and intercalary months be represented by $\mathrm{m}_{S}, \mathrm{~m}_{1}$ and $\mathrm{m}_{\dot{1}}$, and the numbers of saura, lunar and omitted lunar days by $d_{s}, d_{1}$, and $d_{o} \cdot M_{s}$, $M_{1}, M_{i}, D_{S}, D_{1}, D_{0}$ represent similar elements for the time period of Mahayuga

Ahargana $a$ is given by

$$
\begin{aligned}
& a=d_{1}-d_{0} \\
& \text { Clearly } m_{1}=m_{s}+m_{i} \\
& m_{s}=12 y+m \\
& d_{s}=30(12 y+m)+d \\
& d_{1} \text { is variously given by }_{d_{1}}=30 m_{1}+d \\
&=30\left(m_{s}+m_{i}\right)+d \\
&=30\left(12 y+m_{i}\right)+d \\
&=\left[30\left(12 y+m_{i}\right)+d\right]+30 m_{i} \\
&=d_{s}+30 m_{i}
\end{aligned}
$$


$\mathrm{d}_{1}$ can be computed from any one form of eqn. 3 provided $\mathrm{m}_{i}$ be known. $m_{i}$ is calculated from any of the following relations:-

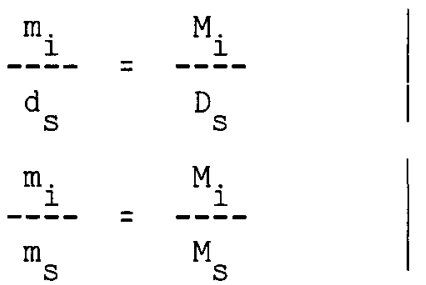

With $d_{1}$ thus computed, $d_{0}$ is determined from:

$$
\frac{\mathrm{d}_{0}}{\mathrm{~d}_{1}}=\frac{\mathrm{D}_{\mathrm{O}}}{\mathrm{D}_{1}}
$$

The ratios $M_{i} / D_{s}, M_{i} / M_{S}, D_{0} / D_{1}$ are found from tables of planetary revolutions given in all sanskrit astronomical texts. Values of $M_{S}, M_{1}$, $M_{i} D_{S}, D_{1}, D_{0}$ as computed from a few texts are given in Table 2.

TABLE 2

REVOUUTION NUMBERS OF THE SUN, MOON AND ASTERISMS AS GIVEN IN VARIOUS TEXTS AND THE VALUES OF $M_{S}, M_{1}, M_{i} D_{S}, D_{1}, D_{0}$

\begin{tabular}{|c|c|c|c|c|}
\hline No.of & $\begin{array}{l}\text { Aryabha- } \\
\text { țyya , } \\
\text { Mahābhās- } \\
\text { karīya, } \\
\text { Laghubhās- } \\
\text { karīya }\end{array}$ & $\begin{array}{l}\text { Khanda- } \\
\text { khādyaka, } \\
\text { Sūryasid- } \\
\text { dhānta } \\
\text { of PS }\end{array}$ & $\begin{array}{l}\text { Later } \\
\text { Sūrya, } \\
\text { Soma, } \\
\text { Brahmā } \\
\text { etc. } \\
\text { Siddhānta }\end{array}$ & $\begin{array}{l}\text { Paitāmaha } \\
\text { siddhānta } \\
\text { of the } \\
\text { Vișnudhar- } \\
\text { mottara }\end{array}$ \\
\hline revl. of the Sun & 4320000 & 4320000 & 4320000 & 4320000 \\
\hline revl. of the Moon & 57753336 & 57753336 & 57753336 & 57753300 \\
\hline revi. of the Asterisms & 1582237500 & 1582237800 & 1582237828 & 1582236450 \\
\hline Civil days & 1577917500 & 1577917800 & 1577917828 & 1577916450 \\
\hline Saura Months (Ms) & 51840000 & 51840000 & 51840000 & 51840000 \\
\hline Lunar months (M1) & 53433336 & 53433336 & 53433336 & 53433300 \\
\hline Intercal.months (Mi) & 1593336 & 1593336 & 1593336 & 1593300 \\
\hline Saura days (Ds) & 1555200000 & 1555200000 & 1555200000 & 1555200000 \\
\hline Lunar days (D1) & 1603000080 & 1603000080 & 1603000080 & 1602999000 \\
\hline Omitted lunar days $\left(D_{0}\right)$ & 25082580 & 25082280 & 25082252 & 25082550 \\
\hline
\end{tabular}

These ratios involve operations with large numbers and their simplification. Some of the simplified forms given in astronomical texts are given below:- 


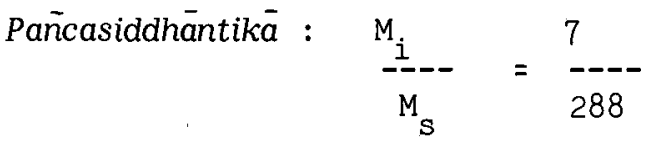

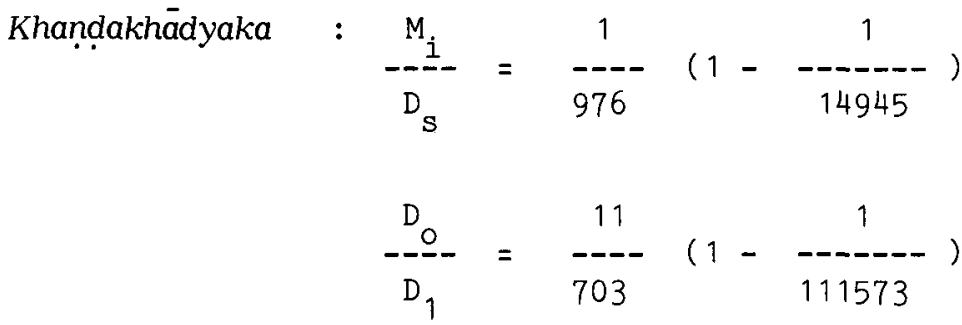

The mean position of each planet is obtained by dividing the ahargana by the period in days of the planet and converting the remainder in degrees, minutes and seconds. This is the mean position or madhyama graha because uniform speed of revolutions was assumed in constructing the tables. To account for non-uniform motions of planets and to introduce quantitatively the two corrections due to two inequalities called manda and sighra the geometry of eccentric circles and epicycles was used.

GEOMETRY OF ECCENTRIC CIRCLES AND EPICYCLES FOR MANDA AND SIGHRA CORRECTIONS.

For the first inequality, the manda correction, two eccentric circles of the same radius or one circle and an epicycle with its centre on the deferent has been used (Figs.1 and 2). A AOP is the apse line or nícocca rekhā

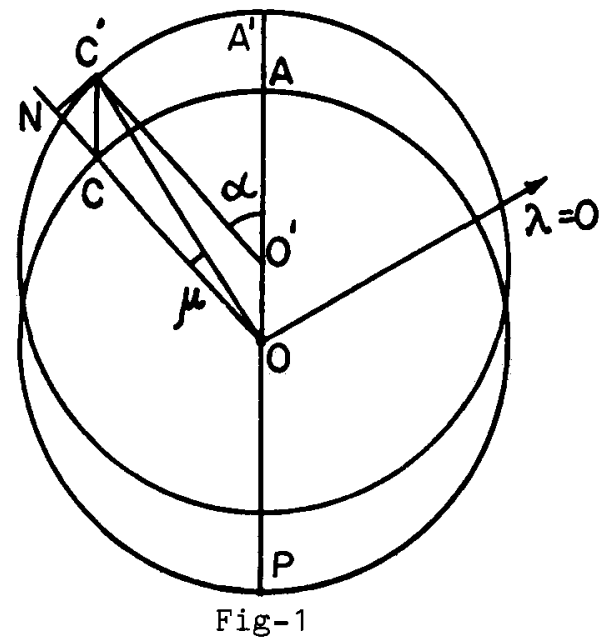

Eccentric model

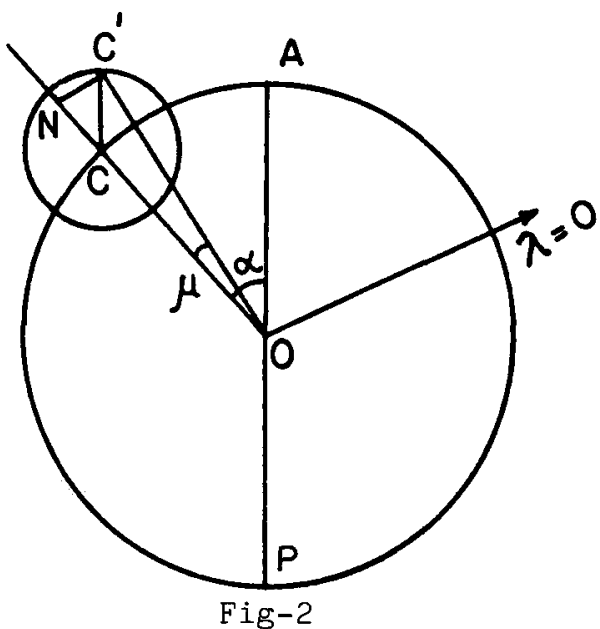

Epicyclic model

$\lambda=0$ is the First Point of Aries or the starting point of planetary revolutions. The mean planet revolves on the deferent circle with 
centre 0 , while the true planet moves on the eccentric circle with centre $0^{\prime}$, in the same anticlockwise direction with the same angular velocity. In the epicycle model the true planet moves on the epicycle with the same angular velocity but in the clockwise direction. The mean and the true planet both have the same longitude at the apogee (mandocca) and perigee, but in between the true planet lags behind the mean in one half of the circle and advances over it in the other half. The angular difference $\mathrm{COC}^{\prime}$ is the equation of centre or mandaphala which may be expressed as follows:

$$
\mathrm{R} \sin \mu=\frac{\mathrm{R} \cdot \mathrm{r} \sin \alpha}{\sqrt{(\mathrm{R}+r \cos \alpha)^{2}+(r \sin \alpha)^{2}}}
$$

where $R$ is the radius of the deferent circle, $r$ the eccentricity or radius of the epicycle, and $\alpha$ the anomaly, that is the difference of longitudes of mean planet and the apogee. If $r$ be neglected compared to $R$, eqn. 6 reduces to

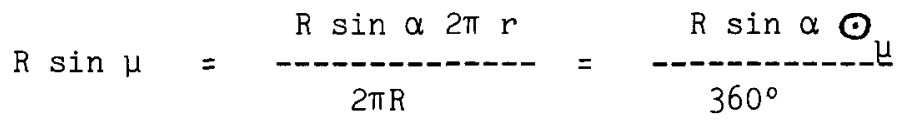

The astronomical siddhāntas prepared in the Āryabhața school do not make this approximation in the hypotenuse for the manda correction while it is done in the surya-siddhanta and other texts. $2 \pi R$ or $360^{\circ}$ is the circumference of the deferent circle or Kakșaurtta and $2 \pi r$ or $\odot_{\mu}$ the circumference of the epicycle.

\section{THE SECOND INEQUALITY OR THE ŚIGGHA CORRECTION}

For the Sun and the Moon, the manda correction is

sufficient, but for the remaining five star-planets, a further sighra correction due to conjunction with the Sun is necessary. This is achieved by having recourse to another eccentric circle or an epicycle called the sighra parivrtta. The geometrical models are shown in Figs. 3 and 4 . After finding the corrected position $C^{\prime}$ upon manda correction, the sighra epicycle is described with $C^{\prime}$ as centre. In it the true planet moves directly, that is anticlockwise direction, such that the direction of the planet from $C^{\prime}$ is always parallel to that of the sun from 0 the centre of the deferent circle. 


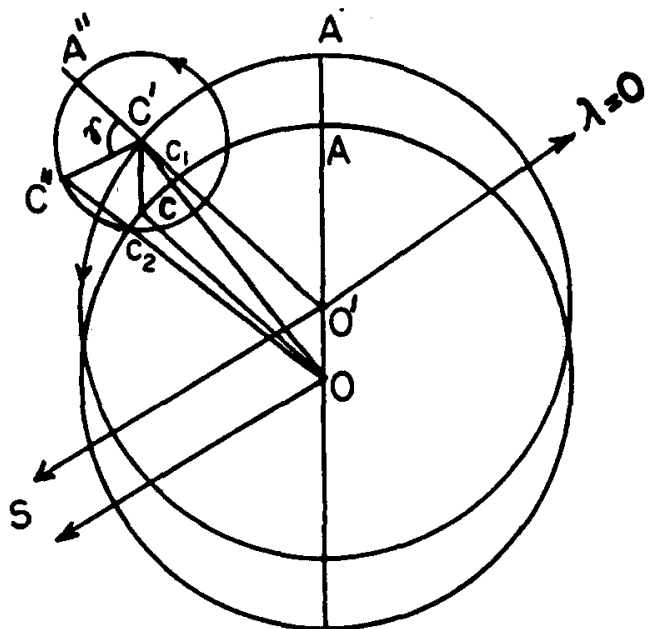

Fig -3

Eccentric - epicyclic model for planets other than the Sun or Moon

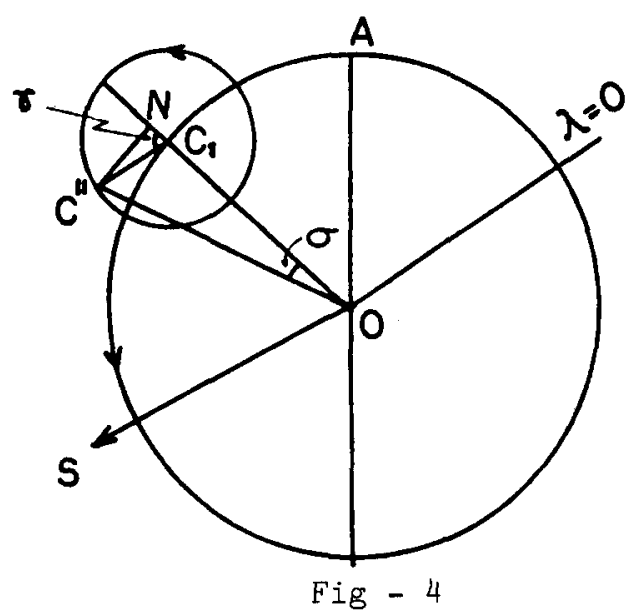

Eccentric - epicyclic model for planets with approximation

Join $C$ "O cutting the deferent circle at $C_{2}$ which is the corrected position of the planet. To simplify the calculations the sighra epicycle is drawn with $\mathrm{C}_{1}$ on the deferent circle as centre. $\mathrm{C}_{1}$ is the intersection of C'O. The sighra correction $\sigma$ is given by

$$
R \sin \sigma=\frac{R r_{1} \sin \gamma}{\sqrt{\left.\left(R+r_{1} \cos \gamma\right)^{2}+r_{1} \sin \gamma\right)^{2}}}
$$

Here $r$, is the radius of the sighra epicycle, $\gamma$ the sighra anomaly, that is, the longitude difference of the Sun and the mean planet after the manda correction.

It is clear from the formulae for manda and 'sighra corrections that the values of certain constants must be known. These are the longitudes of apogee and the dimensions of manda and sighra epicycles of different planets. These constants are given in all texts. An interesting feature of the epicyclic theory is that the dimensions of the epicycles vary according as the mean planets are in the odd or even quadrants.

Finally, the full values of the manda and sighra corrections are not directly applied to the mean longitude of the planet to obtain its true longitude; instead a method of proceeding by half corrections in four steps is followed. These four steps given by Āryabhata and explained by his commentator Parameśvara (Kälakriyă, 22-23) are as follows.

\section{First step}

The longitude of apogee (mandocca) is deducted from that of the mean planet and mandaphala is determined; half of the result is added to or subtracted from mean planet. 


$$
\alpha=\lambda-\lambda A ; \quad \mu_{1}=\mu(\alpha) ; \lambda_{1}=\lambda \pm \mu_{1} / 2
$$

Second step

Deduct the longitude of the mean planet as corrected by step 1 from that of sighrocca (Sun) and find the sighraphala; half of the result is added to or subtracted from the mean planet corrected by step 1 .

$$
\gamma_{1}=\lambda_{S}-\lambda_{1} \neq \sigma_{1}=\sigma\left(\gamma_{1}\right) ; \lambda_{2}=\lambda_{1} \pm \sigma_{1} / 2
$$

Third step

The longitude of the apogee is deducted from that of the mean planet as corrected by steps 1 and II and the mandaphala is determined; the result is added to the original uncorrected mean planet to obtain the corrected mean planet (sphutamadhya),

$$
\alpha_{1}=\lambda_{2}-\lambda_{A} ; \mu_{2}=\mu\left(\alpha_{1}\right) ; \lambda_{3}=\lambda \pm \mu_{2}
$$

Fourth step

The longitude of the (sphutamadhya) is deducted from that of the sighrocca and the corresponding sighraphala determined; apply the result to the (sphutamadhya) to get the true planet.

$$
\gamma_{2}=\lambda_{S}-\lambda_{3} ; \sigma_{2}=\sigma\left(\gamma_{2}\right) ; \lambda=\lambda_{3} \pm \sigma_{2}
$$

A reometrical explanation of the procedure by half mandaphala and half sighraphala was given by Neugebauer (1956). These steps are warranted by the simplifications and approximations introduced in the geometrical models and by the fact that the deferent circle is not large enough compared to the size of the epicycle.

Thus by the fifth century A.D. all the fundamental steps for computing planetary positions from a few set of tables were worked with fair degree of accuracy and embodied in Sanskrit astronomical texts. In the following centuries the methods continued to be elaborated and refined and formed the core of a sizable astronomical literature in texts, procedural manuals and commentaries.

\section{NOTES}

1 The concept of tithi is not attested in Greek texts. It is found in astronomical cuneiform texts, although, unlike the Sanskrit astronomical texts no name is given to the lunar day (Neugebauer 1952, 1955).

\section{REFERENCES}

Äryabhatīya, edited by H.Kern, 1874; English translation by W.E. Clark, 1930; edited by K.V. Sarma and K.S. Shukla with English translation by K.S. Shukla, (1976), Indian National Science Academy, New Delhi. 
Bhattacharyya, S.P., and Sen, S.N., (1969), Ahargana in Hindu astronomy, Indian Journal of History of Science, 4 ; Nos. 1 and 2, 144- 155 .

Candraprajñaptisütra, edited with text in Hindi, Amolakrisi, Hyderabad, Vikramsamvat, 2445; see H.L. Kapadia, Indian Historical Quarterly,8, 1932 pp.381-82; S.R. Das, Indian Historical Quarterly, 8, 1932.pp.36ff.

Neugebauer,o.(1952). The Exact Sciences in Antiquity, pp.123, 178, Capenhagen.

-(1955). Astronomical Cuneiform Texts, 1,p.40.

-(1956), Transmission of planetary theories in ancient and medieval astronomy, Scripta Mathematica, 22, 174 , pp.
Pañcasiddhăntikă, edited by S. Dvivedi and G. Thibaut, 1889; edited by 0 . Neugebauer and D. Pingree, with English translation and notes, 1970-71.

Pañcasiddhäntikā, I, 15; the numbering of the verse is from notes, 1970-71. Suryaprajnapti, edited with the commentary of Malayagiri, Agamadaya Samiti, 1918. See G. Thibaut, Journal of the Asiatic Society of Bengal, 49, 1880, pp.107-127, 181-206.

Vedānga Jyotișa, with Somākara's commentary, edited by Sudhākara Dvivedi, 1908; also edited with his own Sanskrit commentary and English translation by R. Shamasastry, 1936.

Waerden, B.L. Van der (1980). The Conjunction of 3102 B.C.; Centaurus,24, $117-131$.

\section{DISCUSSION}

S.M.R. Ansari : Are there various formulae for Ahargana in Sanskrit texts, especially in later texts? Could you dilate on the basic difference between Pre-Ptolemaic \& Indian Planetary model?

S.N. Sen : The ahargana method given in astronomical siddhantas remained the same in all texts, although different versions of the formulas, I explained, were used in different texts.

I have not made any special study of pre-Ptolemaic planetary theories and so I refrain from making any comparison.

S.D.Sharma : You have tried to explain that according to Ketakar śighraphala converts heliocentric positions to geocentric ones. How? Why mandaphala and sigraphala are so named?

S.N. Sen : I have given my explanation according to astronomical siddhäntas. In the geocentric model, for planets other than the Sun and the Moon, a conjunction correction is needed. This correction is the sigraphala and I explained how this is done in the eccentric-epicyclic model. 
In the first inequality mandocca is the apogee and the anomaly is reckoned from the apogee. This anomaly is required for the calculation of the equation of centre and therefore it is called the mandaphala.

Likewise the sighrocca is the farthest point in the sighra epicycle when the superior planet is in conjunction with the sun. As the síghra anamoly, that is, the longitude difference between sun and the mean planet is required for the conjunction or sighra correction, it is called the śighraphala. 